\section{(6) OPEN ACCESS}

'Division of Neurology, Department of Community Health Medicine, Hyogo College of Medicine Graduate School of Medicine, Nishinomiya, Japan ${ }^{2}$ Fujita Shinkeinaika Clinic, Higashiosaka, Japan

\section{Correspondence to}

Professor Kazuo Abe, abe_neurology@mac.com

Accepted 10 February 2017

\title{
Over 10 years MRI observation of a patient with neuronal intranuclear inclusion disease
}

\author{
Kazuo Abe, ${ }^{1}$ Masashi Fujita ${ }^{2}$
}

\section{SUMMARY \\ We present a sporadic neuronal intranuclear inclusion disease (NIID) patient with neuropathy followed by cognitive dysfunction along with brain MRIs findings of leucoencephalopathy. Her cognitive impairment gradually progressed along with abnormal intensity lesions in diffusion-weighted images. This pathological and clinical deterioration resemble pathological process in prion diseases.}

\section{BACKGROUND}

Neuronal intranuclear inclusion disease (NIID) is a progressive neurodegenerative disease characterised by eosinophilic hyaline intranuclear inclusions, which are widely observed in neuronal and somatic cells. ${ }^{1-6}$ NIID has been considered to be a heterogeneous disease with highly variable clinical manifestations such as neuropathy, cerebellar ataxia and dementia, which may occur concomitantly in certain patients. Sporadic and familial patients have been reported, and the onset of disease varies from the infantile stages to late middle age. These factors made the ante mortem diagnosis of NIID difficult, but Sonoe $e t a l^{5}{ }^{6}$ reported possible usefulness of skin or muscle biopsy and suggested a possible antemortem diagnostic biomarker for NIID. However, longitudinal observation of characteristic leucoencephalopathy in NIID has never been reported. In this study, we present a sporadic NIID patient with neuropathy followed by cognitive dysfunction along with brain MRIs findings of leucoencephalopathy.

\section{CASE PRESENTATION}

A 62-year-old woman noticed jingling sensation bilaterally in the feet since she was 52 years old and consulted to our clinic. On the neurological examination, she had sensory disturbances bilaterally in the feet, but her deep tendon reflexes were normal. She had normal findings including her cognitive function. She showed 30 out of 30 in the total scores of mini-mental state examination (MMSE). She showed relatively prolonged sensory nerve conductive velocities (NCVs) $(30 \mathrm{~m} / \mathrm{sec})$ in the median nerves, ulnar nerves and anterior tibial nerves, but had normal motor NCVs in those nerves. The results of NCVs supported that she had neuropathy. On the MRIs, she showed ischaemic lesions in the white matter in the T2-weighted images (TWIs), high-intensity lesion in the corpus callosum in the fluid attenuated inversion recovery (FLAIR) images (figure 1).

During 3 years from the first admission, she gradually developed attention deficits and forgetfulness. At that time, she showed 27 out of 30 in the
2007
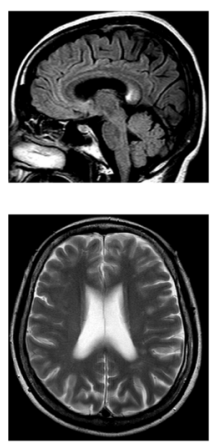

Not Done
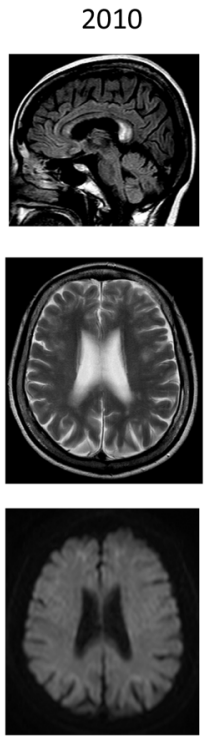

2013
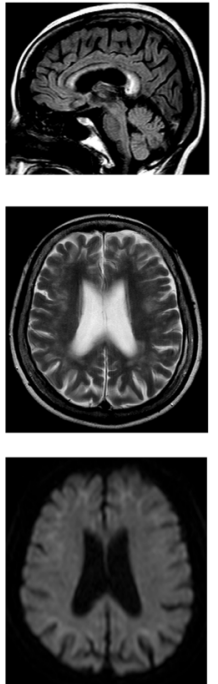

2015
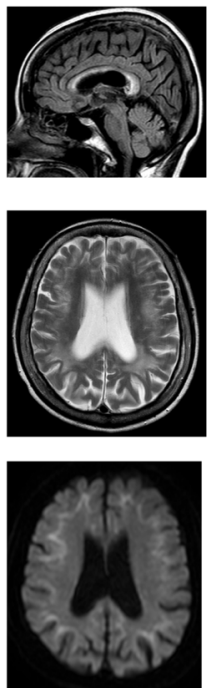

2016
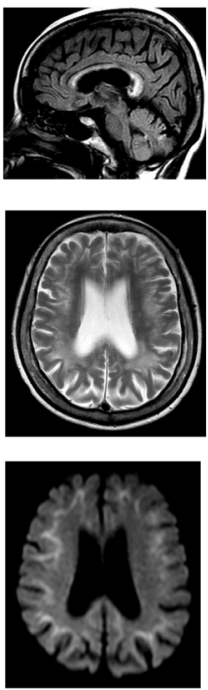

Figure 1 Brain MRI findings. Brain MRI findings showed leucoencephalopathy in T2-weighted and fluid attenuation recovery (FLAIR) images, and showed high-intensity lesions in the corpus callosum. On diffusion-weighted images (DWIs), high intensities were observed from the corticomedullary junction to around the root of gyrus. These abnormal MRI findings were gradually expanded from the frontal to the occipital that were more prominent in DWls. 
total scores of MMSE. On the MRIs, in addition to findings in the first admission, she showed high-intensity lines along with U-fibres in diffusion-weighted images (DWIs). In the consecutive MRIs, these findings in the MRIs gradually worsened (figure 1). However, at 10 years after the first admission, her neuropathy remained as the level of the first admission. She had attention deficits and forgetfulness and showed 26 out of 30 in the total scores of MMSE.

\section{OUTCOME AND FOLLOW-UP}

We followed her in this time.

\section{DISCUSSION}

We reported a patient of leucoencephalopathy with NIID who presented with cognitive dysfunction. The high intensity of the U-fibres in the DWIs is a characteristic finding in NIID that imply existence of intranuclear inclusions in the cerebral cortex. The parallel MRI changes in the DWIs along with cognitive decline supports those U-fibres changes in the DWIs play a pathogenic role in NIID. Sone $\mathrm{et}_{\mathrm{al}} \mathrm{l}^{7}$ recently reported clinicopathological features of NIID, and in that sporadic patients developed initially dementia followed by sensory disturbances, ataxia. Our patient has no family history and developed sensory disturbances followed by dementia. Her sensory disturbances remain rather unchanged, but cognitive impairment gradually progressed along with abnormal intensity lesions in DWIs. Her initial symptom was forgetfulness and inattention. Her total scores in MMSE deteriorated from 30 to 26 and those of frontal assessment battery from 18 to 16 due to verbal influency. This pathological and clinical deterioration resemble pathological process in prion diseases that implies similar pathological processes affected in NIID. Recently, on the basis of neuropathological studies, Masuda-Suzukake $\mathrm{M}$ et $a l^{8}$ indicated that $\alpha$-synuclein fibrils have prion-like properties ${ }^{9}$ and inoculation into wild-type brain induces $\alpha$-synuclein pathology in vivo.

Accumulation of consecutive MRI observation in NIID patients may be useful to elucidate the mechanism of pathological processes affected in NIID.

This is the first report to follow MRIs changes for over long period.

\section{Learning points}

- Neuronal intranuclear inclusion disease (NIID) is a progressive neurodegenerative disease characterised by eosinophilic hyaline intranuclear inclusions.

- MRI observation in NIID patients may be useful.

- Prion-like properties.

Contributors KA performed project development, data collection and manuscript writing. MF performed manuscript writing.

Competing interests None declared.

\section{Patient consent Obtained.}

Provenance and peer review Not commissioned; externally peer reviewed.

Open Access This is an Open Access article distributed in accordance with the Creative Commons Attribution Non Commercial (CC BY-NC 4.0) license, which permits others to distribute, remix, adapt, build upon this work non-commercially, and license their derivative works on different terms, provided the original work is properly cited and the use is non-commercial. See: http://creativecommons.org/ licenses/by-nc/4.0/

\section{REFERENCES}

1 Lindenberg R, Rubinstein LJ, Herman MM, et al. A light and electron microscopy study of an unusual widespread nuclear inclusion body disease. A possible residuum of an old herpes virus infection. Acta Neuropathol (Berl) 1968;10:54-73.

2 Takahashi-Fujigasaki J. Neuronal intranuclear hyaline inclusion disease. Neuropathology 2003;23:351-9.

3 Sung JH, Ramirez-Lassepas M, Mastri AR, et al. An unusual degenerative disorder of neurons associated with a novel intranuclear hyaline inclusion (neuronal intranuclear hyaline inclusion disease). A clinicopathological study of a case. J Neuropathol Exp Neurol 1980;39:107-30.

4 Woulfe JM. Abnormalities of the nucleus and nuclear inclusions in neurodegenerative disease: a work in progress. Neuropathol Appl Neurobiol 2007;33:2-42.

5 Sone J, Tanaka F, Koike $\mathrm{H}$, et al. Skin biopsy is useful for the antemortem diagnosis of neuronal intranuclear inclusion disease. Neurology 2011;76:1372-6.

6 Sone J, Kitagawa N, Sugawara E, et al. Skin biopsy is useful for the antemortem diagnosis of neuronal intranuclear inclusion disease. I Neurol Neurosurg Psychiatr 2014;85:354-6.

7 Sone J, Mori K, Inagaki T, et al. Clinicopathological features of adult-onset neuronal intranuclear inclusion disease. Brain 2016;139:3170-86.

8 Masuda-Suzukake M, Nonaka T, Hosokawa M, et al. Prion-like spreading of pathological $\alpha$-synuclein in brain. Brain 2013;136:1128-38.

9 Prusiner SB. Genetic and infectious prion diseases. Arch Neurol 1993;50:1129-53.

Copyright 2017 BMJ Publishing Group. All rights reserved. For permission to reuse any of this content visit

http://group.bmj.com/group/rights-licensing/permissions.

BMJ Case Report Fellows may re-use this article for personal use and teaching without any further permission.

Become a Fellow of BMJ Case Reports today and you can:

- Submit as many cases as you like

- Enjoy fast sympathetic peer review and rapid publication of accepted articles

- Access all the published articles

- Re-use any of the published material for personal use and teaching without further permission

For information on Institutional Fellowships contact consortiasales@bmjgroup.com

Visit casereports.bmj.com for more articles like this and to become a Fellow 